\title{
Parasitic infection of sole Solea solea by Prosorhynchus spp. metacercariae (Digenea, Bucephalidae) in Atlantic nurseries under mussel cultivation influence
}

\author{
Pascal Laffargue ${ }^{1}$, Grégory Baudouin ${ }^{1}$, Pierre Sasal ${ }^{2}$, Christophe Arnaud ${ }^{1}$, \\ Marie-Laure Begout Anras ${ }^{1}$, Françoise Lagardère ${ }^{1, *}$ \\ ${ }^{1}$ CREMA-L'Houmeau (UMR10 CNRS-Ifremer), BP5, 17137 L'Houmeau, France \\ ${ }^{2}$ Laboratoire de Biologie animale, UMR 5555 CNRS, Université de Perpignan, av. de Villeneuve, 66860 Perpignan Cédex, France
}

\begin{abstract}
Cysts of metacercariae were obtained on 2 dates from juvenile sole Solea solea seasampled in an area of mussel cultivation (Pertuis Charentais, Bay of Biscay, France). An initial assessment of parasite genus and infestation level was based on 192 cysts extracted from 2 fish samples, taken in August $(\mathrm{n}=20)$ and December $2000(\mathrm{n}=14)$. Our results confirmed the sole as second intermediate host of bucephalid trematodes of the genus Prosorhynchus, which has not previously been noticed in Atlantic stocks. Prevalence, ca. $65 \%$ on both dates, indicated an substantial infestation of these small fish, with a mean abundance of parasites increasing from August (3.3 \pm 1.1$)$ to December $(8.1 \pm 3.4)$. Cysts were localised in all body parts of the host, and positioning varied depending on sampling date. However, the cephalic area was always the most infested (72.7 and 49.1\% in August and December, respectively). Parasite measurements suggested a protracted infestation process, which may be initiated in spring during sole settlement. Most of the largest metacercariae had the rhynchus characteristics of $P$. crucibulum, though the possibility of them being other species ( $P$. squamatus, $P$. aculeatus) could not be excluded. As Mytilus edulis is the first intermediate host of Prosorhynchus spp., possible relationships between mussel culture and sole parasitosis are discussed.
\end{abstract}

KEY WORDS: Flatfish $\cdot$ Soleidae $\cdot$ Parasite $\cdot$ Platyhelminthes $\cdot$ Bucephalidae $\cdot$ Nursery suitability

\section{INTRODUCTION}

To obtain indicators of nursery suitability under anthropogenic pressure, we examined the growth of young common sole Solea solea (L.) in an area of shellfish culture (the Pertuis Charentais, mid-Bay of Biscay, France). In the course of this study, metacercariae encysted in the inner ear of young sole were noticed on various occasions. These parasites were identified as bucephalid digeneans, with obvious characteristics of the genus Prosorhynchus (Odhner 1905). Several species have been described in this genus, all having complex life cycles, with teleostean fishes as final hosts harbouring the adult form of the parasite, and 2 intermediate hosts. In the northern Atlantic and adjacent waters, 3 species have been recorded most often: P. crucibulum, P. squa- matus and $P$. aculeatus. The final host most often reported for these 3 species is the conger eel Conger conger (Jones 1943, Sey 1968, Bray 1973, Matthews 1973, Papoutsoglou 1976, Muñoz et al. 1989, Santos \& Gibson 2002). Other fish acting as final host include shorthorn sculpin Myoxocephalus scorpius (Chubrik 1952, Coustau 1991), Arctic charr Salvelinus alpinus (Dick \& Belosevic 1981), painted eel Echelus myrus (Radujkovic et al. 1989) and Greenland halibut Reinhardtius hippoglossoides (Arthur \& Albert 1994). Along the eastern and western Atlantic coasts, 2 mussel species are reported as first intermediate host, Mytilus edulis or M. galloprovincialis, with the host species depending on the Prosorhynchus species and study area (Matthews 1973, Sannia \& James 1977, Coustau et al. 1990, Teia dos Santos \& Coimbra 1995, McGladdery et al. 1999). 
Little information is available on the second intermediate host of these 3 Prosorhynchus species. Manter (1931) identified $1 P$. crucibulum in the gill region of bluefish Pomatomus saltatrix (1 out of 11 fish studied in North Carolina), and Rebecq \& Leray (1961) reported metacercariae of the same species in 2 Gobiesocidae off the French Mediterranean coast. Metacercariae or subadults of Prosorhynchus spp. were found in the gut of various fish, for example sea snail Liparis liparis (Munson 1974), bogue Boops boops (Anato et al. 1991) and flounder Pleuronectes flesus (Alvarez et al. 2002) for P. crucibulum, and cod Gadus morhua (Scott 1975, Appy \& Burt 1982, Køie 1984) for P. squamatus. However, these fish seem to have played a more accidental host role. The first and only record of $P$. crucibulum metacercariae and adults in the common sole was from the northern Aegean Sea (Papoutsoglou \& Papaparaskeva-Papoutsoglou 1977).

To gain new insights into young sole infection by these digenean parasites, this study aimed to obtain epidemiological data, specifically identify the parasite, and discuss the potential relationships between mussel culture, sole parasitosis, and the parasite's life cycle. We mapped the cyst locations in the fish body parts, before removing metacercariae from the cysts for measurements, in order to support comparisons of epidemiological data between sampling periods.

\section{MATERIALS AND METHODS}

Field samples of wild 0-group sole were taken by trawling every 2 mo in a subtidal nursery, close to La Rochelle (Pertuis Charentais, French Atlantic coast: $\left.46^{\circ} 15^{\prime} \mathrm{N}, 01^{\circ} 06^{\prime} \mathrm{W}\right)$. Two samples were chosen from opposing seasons and fish were sub-sampled $(\mathrm{n}=20$ and 14) to range within the average size of fish on the sampling dates (26 August and 2 December 2000, respectively).

Individual fish were measured for standard body length (StdL) and wet mass (wM), to the nearest millimetre and decigram, respectively. They were then frozen and stored at $-20^{\circ} \mathrm{C}$, awaiting further analyses. The fish were thawed and dissected to check for parasites. All parasites were removed and counted by noting tissue locations according to 4 groups of positioning: (1) cephalic region, (2) abdominal cavity, (3) muscles (including the subcutaneous metacercariae in this group) and (4) fins. Prosorhynchus metacercariae were removed from their cysts and measured in order to have an estimate of the infection period. Measurements were taken to the nearest $0.01 \mathrm{~mm}$, under an image analysis system coupled to a light microscope, for body length and width (Fig. 1). The rhynchus, usually used as a possible systematic criterion (Matthews
1973), was also measured.

Fulton's condition factor was calculated as $K=(\mathrm{wM} \times$ 100)/StdL ${ }^{3}$, with wM in grams and StdL in centimetres (Bolger \& Connoly 1989). The level of parasite infection was assessed using classical epidemiological parameters: Prevalence, the percentage of infected fish in the fish dissected $(P \%)$; abundance, the average number of parasites in samples; and intensity of infection, the number of parasites found in an infected fish (Bush et al. 1997). In addition, frequency of cyst occurrence for each body part was calculated.

We used non-parametric Kruskal-Wallis and MannWhitney tests to compare data between the 2 sampling dates, and the Kolmogorov-Smirnov test to compare the distribution of cysts in the body parts with a theoretical homogeneous distribution.

\section{RESULTS}

As expected, the fish sampled in December were significantly larger than those sampled in August (MannWhitney, $U=12.5, \mathrm{p}<0.01$ ) (Table 1) and fish in the August sample had a significantly higher condition factor (Mann-Whitney, $U=75, \mathrm{p}=0.023$ ). Despite a tendency toward a reduction in fish condition with

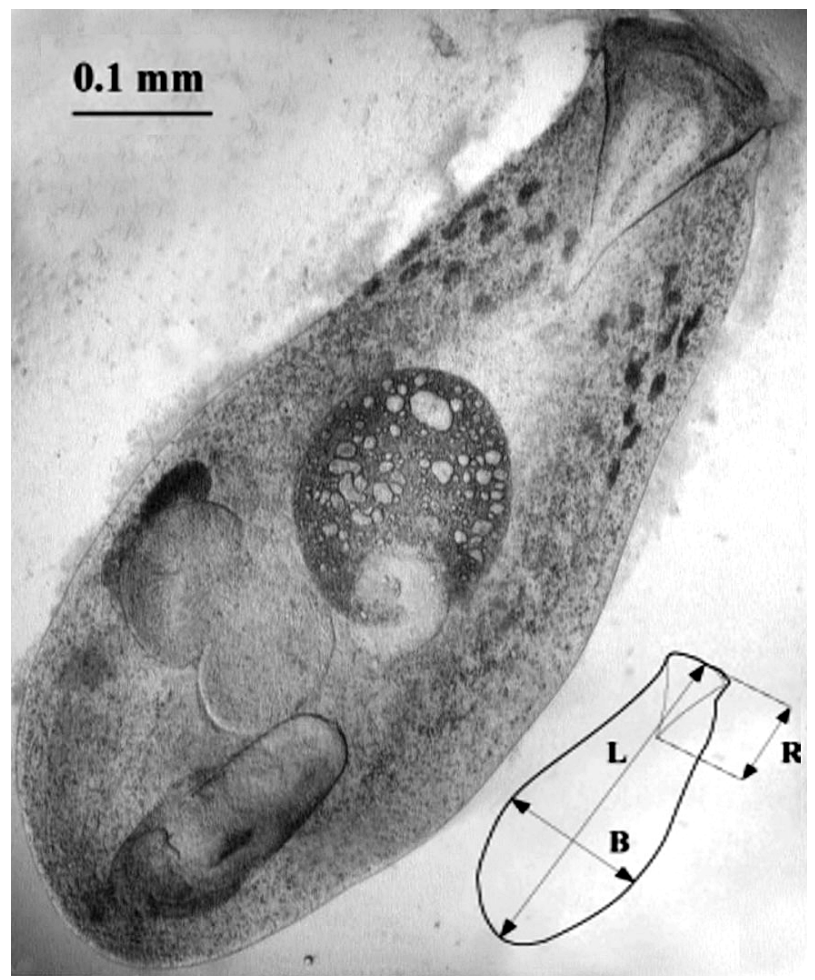

Fig. 1. Prosorhynchus spp. Microphotograph of a metacercaria removed from the cyst, and diagrammatic representation of measurement axes ( $\mathrm{L}=$ length, $\mathrm{B}=$ breadth and $\mathrm{R}=$ rhynchus $)$ 
Table 1. Solea solea. Mean values $( \pm \mathrm{SE})$ of 0 -group sole standard lengths (SdtL in $\mathrm{cm})$, condition factors $\left(K\right.$ in $\left.\mathrm{g} \mathrm{cm}^{-3}\right)$ and epidemiological values of Prosorhynchus cysts for the 2 sampled dates. N = 20 and 14 fish in August and December 2000, respectively. Abundance $=$ mean number of parasites in the studied sample; prevalence $(P \%)=$ percentage of infected hosts in the dissected fish

\begin{tabular}{|c|c|c|c|c|}
\hline & $\begin{array}{l}\text { Mean SdtL } \\
(\min -\max )\end{array}$ & $\begin{array}{c}\text { Mean } K \\
(\min -\max )\end{array}$ & $\begin{array}{c}\text { Mean } \\
\text { abundance } \\
(\min -\max )\end{array}$ & $P \%$ \\
\hline August & $\begin{array}{c}9.9 \pm 0.1 \\
(8.7-11.3)\end{array}$ & $\begin{array}{l}1.06 \pm 0.02 \\
(0.91-1.18)\end{array}$ & $\begin{array}{c}3.3 \pm 1.1 \\
(0-19)\end{array}$ & 65.0 \\
\hline December & $\begin{array}{c}11.2 \pm 0.1 \\
(10.6-12.1)\end{array}$ & $\begin{array}{l}1.00 \pm 0.02 \\
(0.89-1.13)\end{array}$ & $\begin{array}{c}8.1 \pm 3.4 \\
(0-43)\end{array}$ & 64.3 \\
\hline
\end{tabular}

parasite infection intensity in August, there was no significant relationship between the number of Prosorhynchus cysts and the condition factor (simple regressions, $\mathrm{p}>0.05$ for the 2 sampling periods).

A total of 192 metacercariae were obtained from all fish (79 in August and 113 in December). Most of them had a rhynchus invaginated into a triangular cone, with a kidney-shaped indentation observed ventrally at its tip (Fig. 1). The percentage of infected hosts was very similar, between dates $(P \%$ ca. $65 \%$, Table 1$)$ and there was no significant difference in the intensity of infection between samples (Mann-Whitney, $U=127$, $\mathrm{p}>0.05)$. However, mean parasite abundance increased as nursery occupancy continued (3.3 \pm 1.1 and $8.1 \pm 3.4$ in August and December, respectively).

Although cysts were localised in almost all the sole body parts, a considerable number of them were located in the eye area (Fig. 2a), fixed on the adductor muscles or the optic nerves (Fig. 2b), and within the inner ears. Most of the cysts obtained from fish in the August sample were transparent, so the metacercariae could be seen (Fig. 2a), whereas cysts from the December sample formed fibrous capsules (Fig. 2b,c). Percentages of occurrence varied depending on body region and sampling date: in August and December, respectively, percentages were 72.7 and $49.1 \%$ in the cephalic region, 19.7 and $28.3 \%$ in the muscles, 7.6 and $4.7 \%$ in the abdominal cavity and 0 and $17.9 \%$ on the fins. These observed distributions were, not surprisingly, significantly different from a homogeneous distribution (Kolmogorov-Smirnov, $D=0.48, \mathrm{~N}=108$ in August, and $D=0.26, \mathrm{~N}=66$ in December, $\mathrm{p}<0.01$ in both cases). Even if the metacercariae found in the fin areas seemed smaller than the others (Fig. 3), there was no significant difference between metacercarial measurements, whatever the positioning in the sole body, either when considering the 2 samples together or separately (Kruskal-Wallis, p > 0.05 for all comparisons).
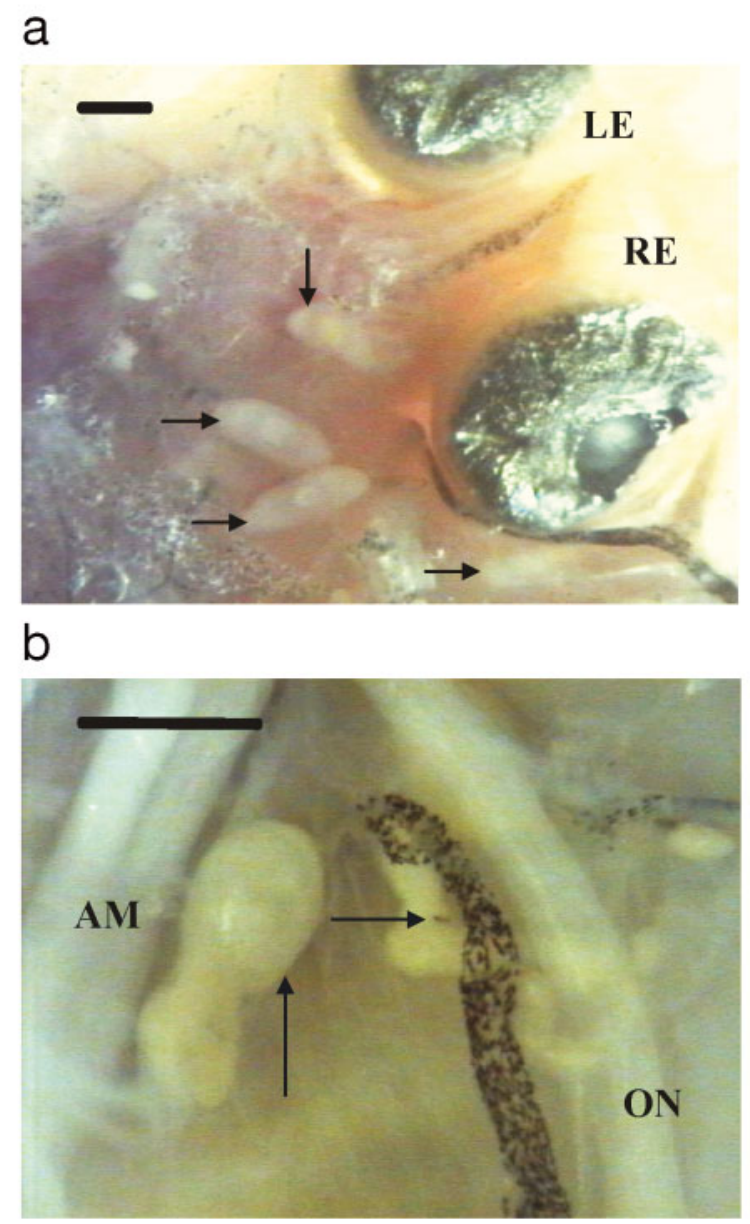

C

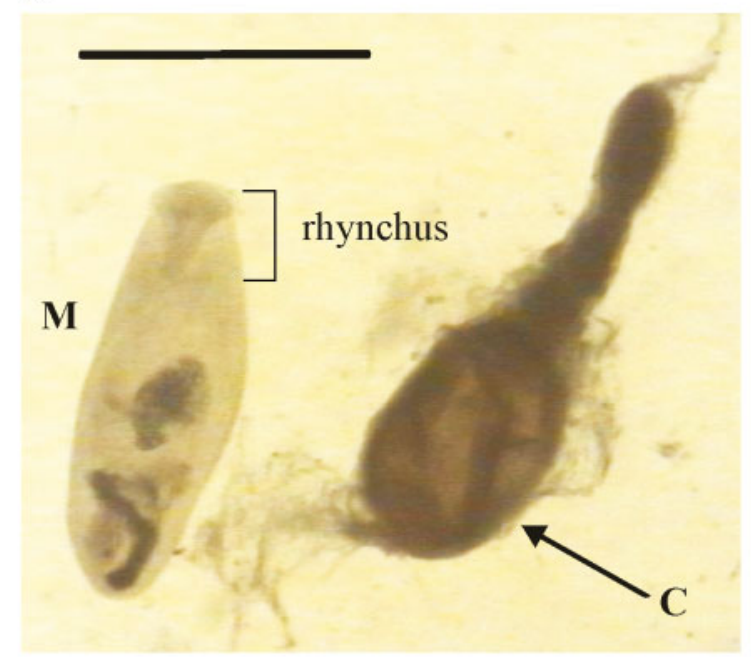

Fig. 2. Microphotographs of Prosorhynchus spp. metacercarial cysts in the eye region of Solea solea, (a, August sample; b, December sample), and removed from the otic capsule with the Prosorhynchus spp. metacercaria removed from the cyst (c, December sample). LE and RE: left and right eye, respectively; AM: adductor muscle; ON: optic nerve; M: metacercaria; C: cyst. Arrows indicate metacercarial cysts in (a) and

(b) and a fibrous cyst in (c). Scale bars $=1 \mathrm{~mm}$ 


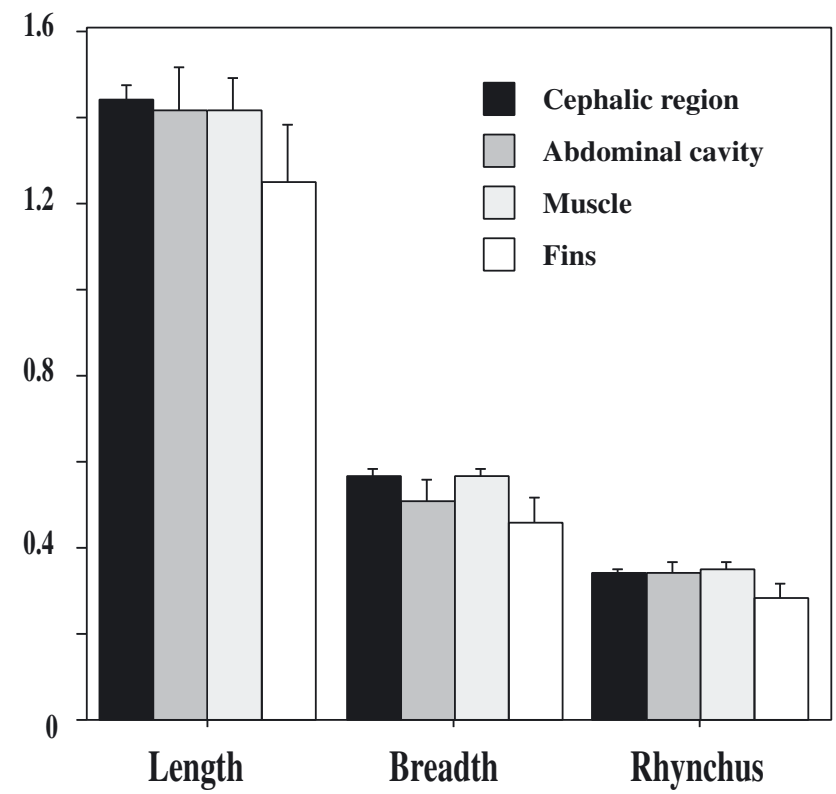

Fig. 3. Mean sizes (mm) of Prosorhynchus spp. metacercariae, with regards to position in the body of sole Solea solea. Bars represent standard errors

Of the 192 parasites counted, 37 (August) and 78 (December) metacercariae were removed from their cysts and measured (Table 2). Rhynchus measured on average $0.35 \pm 0.08 \mathrm{~mm}$ and up to $0.56 \mathrm{~mm}$ in the most developed metacercariae. Though varying in a wide range of sizes for each sampling date, these parasites were significantly longer in August (Mann-Whitney, $U=1013, \mathrm{p}=0.01$ ), while both breadth and rhynchus sizes were not significantly different between dates (Mann-Whitney, p > 0.05).

\section{DISCUSSION}

Previous studies investigating common sole diseases targeted coastal or fisheries management (Newell et al. 1979, Alvarez et al. 2002), as well as mariculture (McVicar \& White 1982, Liewes 1984). The first mention of Prosorhynchus crucibulum in sole is from Papoutsoglou \& Papaparaskeva-Papoutsoglou (1977), where the sole being investigated had the role of both second intermediate host (prevalence ca. 3\% of 180 fish, metacercarial cysts being attached to fins, stomach epithelium and liver) and final host (ca. $6 \%$ of 180 fish, with adult parasites found in the stomach). However, the infection level was low, whereas 1 young sole out of 3 was infested in our studied area (ca. $65 \%$ of 34 fish). Prosorhynchus spp. remain latent throughout the Atlantic, and cause local mussel diseases (castration and death, Coustau et al. 1993, review in McArthur \& McGladdery 2000). This suggests that this
Table 2. Mean values $( \pm \mathrm{SE}$ ) and size range (in $\mathrm{mm}$ ) of the measured Prosorhynchus metacercariae ( $\mathrm{N}=37$ and 78 cysts, in August and December 2000, respectively) from dissected juvenile sole Solea solea on both sampling dates

\begin{tabular}{|lccc|}
\hline & $\begin{array}{c}\text { Mean length } \\
(\min -\mathrm{max})\end{array}$ & $\begin{array}{c}\text { Mean breadth } \\
(\text { min-max })\end{array}$ & $\begin{array}{c}\text { Mean rhynchus } \\
\text { length } \\
\text { (min-max) }\end{array}$ \\
\hline August & $1.54 \pm 0.05$ & $0.54 \pm 0.02$ & $0.36 \pm 0.01$ \\
& $(0.97-2.26)$ & $(0.24-0.73)$ & $(0.25-0.55)$ \\
December & $1.37 \pm 0.04$ & $0.57 \pm 0.01$ & $0.34 \pm 0.01$ \\
& $(0.58-2.81)$ & $(0.27-0.77)$ & $(0.13-0.56)$ \\
\hline
\end{tabular}

type of endemic parasite is very likely to occur in benthic fish liable to harbour metacercarial cysts, whatever the geographic area.

As specific parasite determination is usually based on morphological characters of the adult, which are not complete in metacercariae, parasites encysted in sole could be Prosorhynchus crucibulum, P. squamatus and/or $P$. aculeatus, which are widespread throughout the oceans. From metacercarial rhynchus features, some of our records could be assigned to $P$. squamatus or $P$. aculeatus. However, most of the developed metacercariae had the $P$. crucibulum rhynchus in its adult form, with an apical depression invaginated in a large cone (Matthews 1973, Santos \& Gibson 2002). This allows us to distinguish almost all the metacercariae of the 2 other species from those of P. crucibulum, and to confirm sole as being involved in the life cycle of this parasite species.

Prosorhynchus squamatus and P. crucibulum were responsible, respectively, for parasitosis in long-line cultured mussels from the northern Bay of Biscay (Coustau et al. 1990), and in raft-cultured mussels from the north-western coasts of Portugal (Teia dos Santos \& Coimbra 1995). In our study, fish originated from the Pertuis Charentais, the most important sole nursery (Le Pape et al. 2003) and mussel culture area in the Bay of Biscay. Routine surveys (Ifremer-REPAMO) of shellfish diseases during the same year did not reveal equivalent levels of digenean parasitosis in mussel Mytilus edulis (Thébault et al. 2001). In the range of metacercarial sizes measured in the August sample, the eldest, i.e. the largest, parasites could have entered the fish in March, and the smallest only 2 wk before capture (Matthews 1973). This indicates that the very beginning of infestation may have occurred in newly settling sole from spring onwards, which could indicate a local infestation. Furthermore, cysts obtained from the December-sampled fish formed fibrous capsules, which were not observed in August. As this process requires 2 mo once cercarial encapsulation has occurred, it is consistent with the hypothesis of a tem- 
poral coincidence between the parasite's life cycle (maximal release of cercariae in spring) and the timing of the Bay of Biscay sole settlement (completed in early summer, Amara et al. 2000).

Although fish condition seemed unaffected, the strategic position of metacercariae encysted in sole was striking, especially for those located around the eyeball and within the otocyst. This suggests that this type of infection could impair some biological functions. Sole of the Pertuis Charentais nursery has recently been shown to achieve lower condition and growth rates than those of northern nurseries (P. Laffargue unpubl. data). This suggests a less suitable nursery, possibly due to limitation in the availability of food, with infested fish having to compensate for the energetic cost of being parasitized. More subtle effects of the parasite on fish could be underlying, albeit not detectable with global indices such as condition factor (e.g. behavioural or physiological capabilities, Moore \& Gotelli 1990, Kuris 1997).

Parasitosis due to metacercarial cysts of Prosorhynchus spp. was reported to be of economic importance due to depreciation in the value of fish fillets (Liston et al. 1960). In the context of sustainable coastal management, more attention is being paid to food webs in areas under shellfish culture influence (Leguerrier et al. 2003). In this respect, the parasite load in fish is an appropriate tool, since it often reveals imbalance(s) at the fish and nursery level(s) (Dale \& Beyeler 2001, Whittfield \& Elliot 2002). To open up new prospects, more work is in progress, especially to establish what exactly the relationships are between mussel culture, the life cycles of parasites, and the effects of this parasitic infection in a species of high commercial value in northeastern Atlantic fisheries.

Acknowledgements. We greatly thank C. Coustau for fruitful discussions. This study received financial support from French Programmes on coastal and fisheries management (Programme National Environnement Côtier and Défi Gascogne) and the Conseil Général of Charente-Maritime (grant to P.L). It was conducted under the approval of the French Animal Care Committee-Official licence no. 02526 (J. P. Lagardère).

\section{LITERATURE CITED}

Alvarez F, Iglesias R, Pamara AI, Leiro J, Sanmartin M (2002) Abdominal parasites of commercially important flatfishes (Teleostei: Scophthalmidae, Pleuronectidae, Soleidae) in northwest Spain (ICES IXa). Aquaculture 213:31-53

Amara R, Lagardère F, Désaunay Y, Marchand J (2000) Metamorphosis and estuarine colonisation in the common sole, Solea solea (L.): implications for recruitment regulation. Oceanol Acta 23:469-484

Anato CB, Ktari MH, Dossou CH (1991) La parasitofaune métazoaire de Boops boops (Linné, 1758), poisson téléostéen Sparidae des côtes tunisiennes. Oebalia 17:259-266
Appy RG, Burt MDB (1982) Metazoan parasites of cod, Gadus morhua L., in Canadian Atlantic waters. Can J Zool 60: 1573-1579

Arthur JR, Albert E (1994) A survey of the parasites of Greenland halibut (Reinhardtius hippoglossoides) caught off Atlantic Canada, with notes on their zoogeography in this fish. Can J Zool 72:765-778

Bolger T, Connoly PL (1989) The selection of suitable indices for the measurement and analysis of fish condition. J Fish Biol 34:171-182

Bray RA (1973) Some digenetic trematodes in fishes from the Bay of Biscay and nearby waters. Bull Br Mus Nat Hist (Zool) 26:149-183

Bush AO, Lafferty KD, Lotz JM, Shostak AW (1997) Parasitology meets ecology on its own terms: Margolis et al. revisited. J Parasitol 83:575-583

Chubrik GK (1952) On the life cycle of the fish trematode, Prosorhynchus squamatus Odhner, 1905. Dokl Akad Nauk SSSR 83:327-329

Coustau C (1991) Analyse génétique et physiologique des interactions hôte-parasite: le système Prosorhynchus squamatus-Mytilus. PhD thesis, University of Montpellier II, p 1-133

Coustau C, Combes C, Maillard C, Renaud F, Delay B (1990) Prosorhynchus squamatus (Trematoda) parasitosis in the Mytilus edulis - Mytilus galloprovincialis complex: specificity and host-parasite relationships. In: Cheng TC, Perkins FO (eds) Pathology in marine science. Academic Press, London, p 291-298

Coustau C, Robbins I, Delay B, Renaud F, Mathieu M (1993) The parasitic castration of the mussel Mytilus edulis by the trematode parasite Prosorhynchus squamatus: specificity and partial characterization of endogenous and parasiteinduced anti-mitotic activities. Comp Biochem Physiol A 104:229-233

Dale VH, Beyeler SC (2001) Challenges in the development and use of ecological indicators. Ecol Indic 1:3-10

Dick TA, Belosevic M (1981) Parasites of Arctic charr Salvelinus alpinus (Linnaeus) and their use in separating sea-run and non-migrating charr. J Fish Biol 18:339-347

Jones DO (1943) The anatomy of three digenetic trematodes, Skrjabiniella aculeatus (Odhner), Lecithochirium rufoviride (Rud.) and Sterrhurus fusiformis (Lühe) from Conger conger (Linn.). Parasitology 35:40-57

Køie M (1984) Digenetic trematodes from Gadus morhua L. (Osteichthyes, Gadidae) from Danish and adjacent waters, with special reference to their life-histories. Ophelia 23: 195-222

Kuris AM (1997) Host behavior modification: an evolutionary perspective. In: Beckage NE (ed) Parasites and pathogens - effects on host hormones and behavior. Chapman \& Hall, New York, p 293-315

Leguerrier D, Niquil N, Boileau N, Rzeznik J, Sauriau PG, Le Moine O, Bacher C (2003) Numerical analysis of the food web of an intertidal mudflat ecosystem on the Atlantic coast of France. Mar Ecol Prog Ser 246:17-37

Le Pape O, Chauvet F, Mahevas S, Lazure P, Guérault D, Désaunay Y (2003) Quantitative description of habitat suitability for the juvenile common sole (Solea solea, L.) and contribution of different habitats to the adult population in the Bay of Biscay (France). J Sea Res 50:139-149

Liewes EW (1984) Culture, feeding and diseases of commercial flatfish species. Balkema AA, Rotterdam, p 1-104

Liston J, Peters J, Stern JA (1960) Parasites in summer-caught Pacific rockfishes. US Fish and Wildlife Services, Washington, Special Scientific Report, Fisheries, No. 352, p i-iii $+1-10$ 
Manter HW (1931) Some digenetic trematodes of marine fishes of Beaufort, North Carolina. Parasitology 23:396-411

Matthews RA (1973) The life-cycle of Prosorhynchus crucibulum (Rudolphi, 1819) Odhner, 1905, and a comparison of its cercaria with that of Prosorhynchus squamatus Odhner, 1905. Parasitology 66:133-164

McArthur F, McGladdery SE (2000) Prosorhynchus squamatus (Digenea: Platyhelminthes) infection of blue mussels (Mytilus edulis) in Atlantic Canada. Final Report for DFOScience and Technology, Internship Program 1997/98. Department of Fisheries and Oceans Canada, Moncton, NB, $\mathrm{p} 1-13$

McGladdery SE, Stephenson MF, McArthur F (1999) Prosorhynchus squamatus (Digenea: Platyhelminthes) infection of blue mussels, Mytilus edulis, in Atlantic Canada. J Shellfish Res 18:297 (Abstract)

McVicar AH, White PG (1982) The prevention and cure of an infectious disease in cultivated juvenile Dover sole, Solea solea (L.). Aquaculture 26:213-222

Moore JK, Gotelli NJ (1990) A phylogenetic perspective on the evolution of altered host behaviours: a critical look at the manipulation hypothesis. In: Barnard CJ, Behnke JM (eds) Parasitism and host behaviour. Taylor \& Francis, London, p 193-233

Muñoz MV, Fernandez JP, Carbonell E, Orts ME (1989) Contribution to the study of some bucephalids (Trematoda: Bucephalidae), parasites of marine fish in Iberian waters. Rev Iberica Parasitol 49:27-35

Munson DA (1974) Parasites of the tide pool fish Liparis atlanticus. J Wildl Dis 10:256-262

Newell PF, Appleton TC, Brown BE, Carnwarth JW (1979) Elemental distribution in relation to skin necroses of marine flatfishes from the English Channel. Mar Biol 51:93-99

Odhner T (1905) Die Trematoden des arktischen Gebietes. Fauna Arct 4:289-372

Papoutsoglou SE (1976) Metazoan parasites of fishes from Saronicos Gulf, Athens, Greece. Thalassographica 1:69-102

Editorial responsibility: Wolfgang Körting,

Hannover, Germany
Papoutsoglou SE, Papaparaskeva-Papoutsoglou EG (1977) Metazoan parasites of Solea Solea (L.) from Porto-Lago, North Ægean Sea, Greece. Mem Biol Mar Oceanogr 7: 21-33

Radujkovic BM, Orecchia P, Paggi L (1989) Parasites des poissons marins du Monténégro: Digènes. Acta Adriatica 30: 137-187

Rebecq J, Leray C (1961) Metacercaires de Prosorhynchus crucibulum (Rudolphi 1819) (Trematoda, Bucephalidae) chez deux Gobiesocidae (Téléostéens). Vie Milieu 12: $378-380$

Sannia A, James BL (1977) The digenea in marine molluscs from Eyjafjördur, North Iceland. Ophelia 16:97-109

Santos MJ, Gibson DI (2002) Morphological features of Prosorhynchus crucibulum and $P$. aculeatus (Digenea: Bucephalidae), intestinal parasites of Conger conger (Pisces: Congridae), elucidated by scanning electron microscopy. Folia Parasitol 49:96-102

Scott JS (1975) Incidence of trematode parasites of American plaice (Hippoglossoides platessoides) of the Scotian Shelf and Gulf of St. Laurence in relation to fish length and food. J Fish Res Board Can 32:479-483

Sey O (1968) Parasitic helminths occuring in Adriatic fishes. Acta Adriatica 13:3-15

Teia dos Santos AM, Coimbra J (1995) Growth and production of raft-cultured Mytilus edulis L., in Ria de Aveiro: gonad symbiotic infestation. Aquaculture 132:195-211

Thébault A, Robert $M$, Chollet $B$, Dumais $M$ and 6 others (2001) Bilan 2000 du réseau REPAMO (Réseau de Pathologie des Mollusques) - Réseau National de surveillance zoosanitaire des mollusques marins. Ifremer, La Tremblade, Rapport interne nov. 2001, DRV/RA/LGP, p 1-79

Whitfield AK, Elliott M (2002) Fishes as indicators of environmental and ecological changes within estuaries: a review of progress and some suggestions for the future. J Fish Biol 61A:229-250

Submitted: April 14, 2003; Accepted: September 23, 2003 Proofs received from author(s): January 20, 2004 